\title{
Araceae of Grumari restinga: contribution to the conservation of the flora of Rio de Janeiro State, Brazil
}

\author{
Luana S.B. Calazans ${ }^{*}$, Rodrigo Theófilo Valadares ${ }^{1}$, Cassia Mônica Sakuragui ${ }^{2}$ and Rosana Conrado Lopes ${ }^{2}$
}

Received: June 5, 2017

Accepted: August 23, 2017

\begin{abstract}
This study surveyed species of the family Araceae in Grumari restinga, located in the metropolitan region of the city of Rio de Janeiro, Brazil. We aimed to: i) evaluate the contribution of a single locality (Grumari restinga) to regional conservation (Rio de Janeiro State) of Araceae; and ii) compare the distribution of species of Araceae among restingas of the state. We calculated the extent of occurrence and the area of occupancy in the entire state for eight species of Araceae found in Grumari,and performed a similarity analysis among restingas. Our data demonstrate that the extent of occurrences for Anthurium augustinum, A. coriaceum and A. maricense are influenced by Grumari because this area is the boundary of their known distribution in the state. Grumari did not have an influence on the distribution of the other studied species. We found Anthurium coriaceum, A. luschnathianum and Philodendron crassinervium to exhibit unusual habits as terrestrial plants in sandy soil. The similarity analysis identified six groups of Araceae, four of which are related to the distance from adjacent forests. We demonstrated that this small conservation unit represents a key locality in the preservation of natural populations of species of Araceae in Rio de Janeiro State.
\end{abstract}

Keywords: conservation status, fragmentation, inventory, phylogenetic stock, species distribution

\section{Introduction}

Restinga is a phytogeographic unit of the Atlantic Forest, encompassing a coastal ecosystem with vegetation on Quaternary sediments that comprises different herbaceous, shrubby and tree communities (Pereira \& Araujo 2000; Pereira 2003). Distribution patterns found in the literature suggest that the species composition of restinga includes taxa from neighboring communities (e.g. dense ombrophilous forest) and species widely distributed in South America (Araujo 2000). The increasing loss of neighboring vegetation, such as montane forest, has resulted in areas of restinga being the last refuges of populations with a previously wider distribution. Many floristic lists have already been produced for restinga areas in the state of Rio de Janeiro (e.g. Pereira \& Araujo 2000), but surveys focused on particular plant families are still scarce (e.g. Cogliatti-Carvalho et al. 2008; Pederneiras et al. 2014). When considering the original extent of restinga in the state and the loss of cover due to real estate speculation, there is an urgent need to conserve this ecosystem (Rocha et al. 2007). Further, fragments of restinga along the Rio de Janeiro coast (from municipality of São João da Barra to the municipality of Paraty) are key areas for the conservation of rare plants (Giulietti et al. 2009) and represent regions of extremely high priority for the conservation of threatened species (Loyola et al. 2014).

Araceae is a striking group to test patterns in restinga, because the family is a conspicuous element of adjacent

1 Programa de Pós-Graduação em Ciências Biológicas (Botânica), Museu Nacional Universidade Federal do Rio de Janeiro, Quinta da Boa Vista, s/n, São Cristóvão, 20940-040, Rio de Janeiro, RJ, Brazil

2 Instituto de Biologia, Universidade Federal do Rio de Janeiro, Rua Rodolpho Paulo Rocco s/n, 21941-490, Rio de Janeiro, RJ, Brazil

* Corresponding author: luanasbcalazans@gmail.com 
humid forest formations (Mayo et al. 1997; Sakuragui et al. 2011). However, the only survey published for the group in Brazilian restingas is restricted to the state of Espírito Santo, where about $50 \%$ of the species of Araceae were determined to be regionally threatened (Valadares et al. 2010; Valadares \& Sakuragui 2016). The few floristic lists that include Araceae in restinga (e.g. Araujo \& Oliveira 1988; Araujo et al. 2009; Pereira \& Araujo 2000; Pereira et al. 2004) are taxonomically outdated due to an increase in systematic studies over the last decade. In addition, data about the conservation of these species in the literature are still inconsistent.

This work surveyed the species of Araceae in Grumari restinga, an area in central-southern Rio de Janeiro state, which has not yet been inventoried. We aimed to: i) evaluate the contribution of a single locality (Grumari restinga) to the regional conservation (state of Rio de Janeiro) of Araceae; and ii) compare Araceae distribution among restingas in the entire state. We also report unusual habits for some species and contribute to the discussion about the potential of using a single area in conservation efforts at a regional level.

\section{Materials and methods}

Study area

Grumari restinga is located in the western zone of the metropolitan area of the city of Rio de Janeiro, Brazil

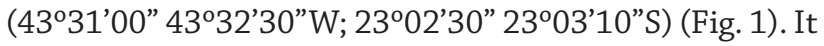
is one of the smallest fragments of restinga in the state of Rio de Janeiro and is frequently subjected to anthropogenic impacts (Vidal \& Vidal 1977/78; Rocha et al. 2007). It has 951 ha within the Grumari Environmental Protection Area (APA Grumari), comprising four formations: halophilouspsammophilous, post-beach, open shrub and restinga forests (Moreira et al. 2014).

\section{Taxonomic circumscription of the species}

Species taxonomy follows the species list of Brazilian flora (BFG 2015) with one exception, the Anthurium augustinum K.Koch \& Lauche complex. The taxonomy of the $A$. augustinum complex follows the taxonomic treatment proposed by Cardozo et al. (2014), who synonymized A. maximilianii Schott, A. laucheanum K.Koch and A. lhotzkyanum Schott under A. augustinum K.Koch \& Lauche based on a morphometric analysis.

\section{Extent of occurrence and area of occupancy}

Firstly, a list of species of Araceae in the study area was compiled based on field expeditions as part of the "Flora of Grumari Project". Secondly, a database was constructed to including the distribution of species in the state of Rio de Janeiro and their regional conservation status (i.e. status at the state level) based on: i) our field data; ii) herbarium records (GUA, HB, R, RB and RFA, acronyms according to Thiers (2016); and iii) SpeciesLink (2016), in all cases using only specimens identified by Araceae specialists. The geographic coordinates of each specimen were taken from their labels. Specimens without original georeferencing had their coordinates estimated using the geoLoc tool on SpeciesLink.

To evaluate the influence of Grumari restinga on regional conservation and distribution of Araceae in restinga areas of the state of Rio de Janeiro, we calculated the extent of occurrence (EOO) and the area of occupancy (AOO) of each Araceae species found in Grumari restinga using the GeoCAT tool (Bachman et al. 2011) and all records from the state. The $\mathrm{AOO}$ and $\mathrm{EOO}$ indexes refer to the distribution of a taxon in a given region: EOO corresponds to the area contained within the smallest convex polygon that can be drawn to include all known sites of occurrence of a taxon; $\mathrm{AOO}$ corresponds to the effective area within the EOO which is actually occupied by a taxon (IUCN 2010). This approach allowed us to assess conservation status at a regional level (Gärdenfors et al. 2001) by applying IUCN (2010) assessment criteria, restricted to the state of Rio de Janeiro in this case. Each species was evaluated based on all the points surveyed for the state (List S1 in supplementary material), considering first the occurrence in Grumari restinga and then excluding it. The objective of this analysis was to show the influence of the Grumari restinga on $\mathrm{EOO}$ and $\mathrm{AOO}$ and, consequently, on the conservation status of each species. This status was compared to those suggested at the state level for the state of Rio de Janeiro by Coelho et al. (2014) and Sakuragui et al. (2011). At the national level, we compared our determined status with the official national list of threatened plant species (Brasil 2014).

\section{Similarity of Araceae in restinga areas of the state of Rio de Janeiro}

To search for the distribution of Araceae species in restinga ecosystems of the state, a list of species was compiled based on: i) our field data; ii) records from the previously cited herbaria; and iii) records from floristic and phytosociological inventories (Araujo \& Oliveira 1988; Lemos et al. 2001; Pereira et al. 2004; Paz \& Bove 2007; Araujo et al. 2009; Carvalho \& Sá 2011). Similarity in species composition among Grumari restinga and other restinga areas was evaluated by using a presence-absence matrix (Tab. 1). We calculated the Jaccard similarity index among areas and constructed a dendrogram using the UPGMA algorithm in the software PAST (Hammer et al. 2001).

\section{Results and discussion}

In this paper, we search for the contribution of Grumari restinga to the conservation of Araceae in the state of Rio 


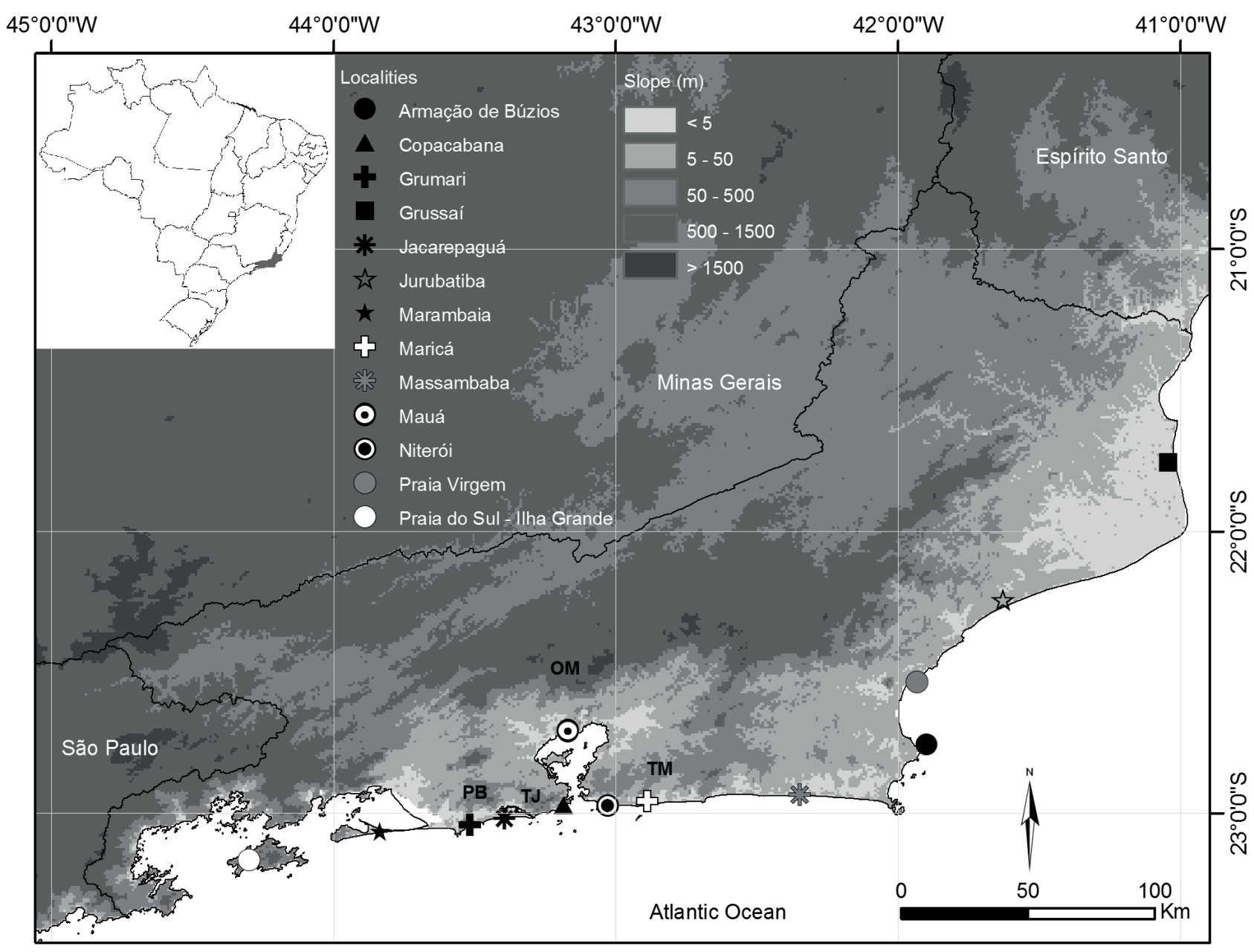

Figure 1. Elevation map showing the location of the Grumari restinga and the remaining areas of restinga in the state of Rio de Janeiro compared in the similarity analysis. OM, Órgãos Mountains; PB, Pedra Branca Massif; TJ, Tijuca Massif; TM, Tiririca Mountains.

de Janeiro and found that the extent of occurrence of only three out of eight species is influenced by Grumari restinga. We also looked for a better understanding of Araceae distribution over restinga ecosystems in the entire state and found that groups of species are related to the distance of the adjacent forests.

\section{Contribution of Grumari restinga to the conservation of Araceae in the state of Rio de Janeiro}

As far as we know, there has been no previous floristic or phytosociological inventory that included Araceae samples from Grumari restinga. Eight species of two genera of Araceae were recorded in Grumari restinga (Tab. 2), and all of the species are endemic to the Atlantic Forest (Coelho et al. 2009). At the regional level, in the state of Rio de Janeiro and according to the extent of occurrence (EOO), only Anthurium intermedium is not threatened, but all other species are. However, taking into account the AOO, all species of Araceae in Grumari restinga are threatened (Tab. 2). Following IUCN (2010) statements, we must consider the most critical status. Generally, our AOO suggested a more threatened category than the EOO. This is due to the close relationship between the $\mathrm{AOO}$ and the number of records used in the analysis, whereas the EOO is influenced only by the occurrence points that modify the vertices of the distribution (Bachman et al. 2011). Most species have relatively few records in the state, which makes regional assessments very sensitive to sampling but not impossible to analyze. When Grumari is excluded, the EOOs of $A$. augustinum, $A$. coriaceum and $A$. maricense are reduced, because this restinga represents a vertex of the polygon. The loss of this area would result either in the decrease of important populations of species with narrow distributions in areas of restinga in the state of Rio de Janeiro, and/ or decrease the occurrence of plants with unusual habits (A. augustinum, $A$. coriaceum, $A$. luschnanthianum and $P$. crassinervium), which are discussed below.

The local extinction of the A. augustinum population in the Grumari restinga would result in the loss of a substantial source of biogeographic knowledge of this species, because Grumari is the last remnant non-island restinga, where $A$. augustinum occurs along the coast of the state (Tab. 1). It is worthwhile to point out that various entities were recently 
Table 1. Presence (1) - absence (0) matrix between the Araceae species and Rio de Janeiro restingas. Species records are from herbaria and floristic and phytosociological inventories. Niterói, Massambaba and Jacarepaguá restingas are compound by several localities: Niterói - Itacoatiara, Itaipú and Piratininga; Massambaba - Araruama, Arraial do Cabo, Cabo Frio and Saquarema; Jacarepaguá Jacarepaguá, Tijuca and Itapeba restingas.

\begin{tabular}{|c|c|c|c|c|c|c|c|c|c|c|c|c|c|}
\hline Species & 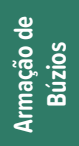 & 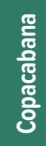 & 돓 & 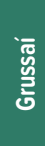 & 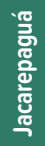 & $\begin{array}{l}\text { 을 } \\
\text { 营 } \\
\text { 록 }\end{array}$ & 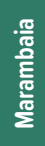 & 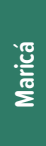 & 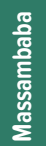 & 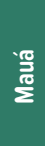 & $\begin{array}{l}\text { : 을 } \\
\text { 妾 }\end{array}$ & $\begin{array}{l}\overline{\overline{5}} \\
\text { 응 } \\
. \frac{0}{0} \\
\frac{0}{0}\end{array}$ & 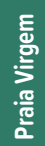 \\
\hline Anthurium augustinum K.Koch \& Lauche & 0 & 0 & 1 & 0 & 0 & 0 & 0 & 0 & 0 & 0 & 0 & 1 & 0 \\
\hline Anthurium coriaceum (Graham) G.Don & 0 & 0 & 1 & 0 & 0 & 0 & 0 & 0 & 0 & 0 & 1 & 0 & 0 \\
\hline Anthurium harrisii (Graham) G.Don & 1 & 0 & 0 & 1 & 1 & 1 & 0 & 1 & 1 & 0 & 1 & 0 & 1 \\
\hline Anthurium intermedium Kunth & 0 & 0 & 1 & 1 & 1 & 1 & 0 & 1 & 1 & 0 & 0 & 1 & 1 \\
\hline Anthurium luschnathianum Kunth & 0 & 0 & 1 & 0 & 1 & 0 & 1 & 1 & 0 & 0 & 0 & 1 & 0 \\
\hline Anthurium maricense Nadruz \& Mayo & 1 & 0 & 1 & 1 & 1 & 1 & 0 & 1 & 1 & 0 & 1 & 0 & 0 \\
\hline Anthurium parasiticum (Vell.) Stellfeld & 0 & 0 & 0 & 0 & 0 & 1 & 1 & 1 & 1 & 0 & 0 & 1 & 0 \\
\hline Anthurium parvum N.E.Br. & 0 & 0 & 0 & 0 & 1 & 0 & 0 & 0 & 0 & 0 & 0 & 0 & 0 \\
\hline Anthurium pentaphyllum (Aubl.) G.Don & 0 & 1 & 0 & 0 & 0 & 1 & 0 & 1 & 1 & 0 & 0 & 0 & 1 \\
\hline Anthurium scandens (Aubl.) Engl. & 0 & 0 & 0 & 0 & 0 & 0 & 0 & 0 & 0 & 0 & 0 & 1 & 0 \\
\hline Asterostigma lividum (Lodd.) Engl. & 0 & 0 & 0 & 0 & 0 & 0 & 0 & 0 & 1 & 0 & 0 & 0 & 0 \\
\hline Heteropsis salicifolia Kunth & 0 & 0 & 0 & 0 & 0 & 0 & 0 & 0 & 0 & 0 & 0 & 1 & 0 \\
\hline Monstera adansonii Schott & 0 & 0 & 0 & 0 & 0 & 0 & 0 & 0 & 1 & 0 & 0 & 1 & 0 \\
\hline Monstera praetermissa E.G.Gonç. \& Temponi & 0 & 0 & 0 & 0 & 0 & 0 & 1 & 0 & 0 & 0 & 0 & 0 & 0 \\
\hline Montrichardia linnifera (Arruda) Schott & 0 & 0 & 0 & 1 & 0 & 0 & 0 & 0 & 0 & 0 & 0 & 0 & 0 \\
\hline Philodendron bipennifolium Schott & 0 & 0 & 0 & 0 & 1 & 0 & 0 & 0 & 1 & 0 & 0 & 0 & 0 \\
\hline Philodendron bipinnatifium Schott ex Endl. & 0 & 0 & 0 & 0 & 0 & 1 & 0 & 0 & 1 & 0 & 0 & 1 & 0 \\
\hline Philodendron corcovadense Kunth & 0 & 1 & 1 & 0 & 1 & 0 & 1 & 1 & 1 & 0 & 1 & 0 & 1 \\
\hline Philodendron cordatum Kunth ex Schott & 0 & 0 & 1 & 0 & 0 & 0 & 0 & 1 & 1 & 0 & 1 & 1 & 1 \\
\hline Philodendron crassinervium Lindl. & 0 & 1 & 1 & 0 & 0 & 0 & 0 & 1 & 0 & 1 & 0 & 1 & 0 \\
\hline Philodendron curvilobum Schott & 0 & 0 & 0 & 0 & 1 & 0 & 0 & 0 & 0 & 0 & 0 & 0 & 0 \\
\hline Philodendron pedatum Schott & 0 & 0 & 0 & 0 & 0 & 1 & 0 & 0 & 1 & 0 & 0 & 0 & 1 \\
\hline Pistia stratioides L. & 0 & 0 & 0 & 0 & 1 & 0 & 0 & 1 & 1 & 0 & 0 & 0 & 0 \\
\hline Syngonium podophyllum Schott & 0 & 0 & 0 & 0 & 0 & 0 & 0 & 0 & 1 & 0 & 1 & 0 & 0 \\
\hline Wolffiella neotropica Landolt & 0 & 0 & 0 & 0 & 0 & 0 & 0 & 0 & 1 & 0 & 0 & 0 & 0 \\
\hline
\end{tabular}

consolidated within A. augustinum (Cardozo et al. 2014) based on a morphometric analysis. However, the Grumari population exhibited easily recognizable entities of this complex (A. lhotzkyanum and A. maximilianii). Although the work of Cardozo et al. (2014) was comprehensive, no restinga population has been analyzed and the lack of a phylogeographic study suggests that the morphological variation of the species in relation to its evolutionary history is still poorly understood.

The Grumari population of A. coriaceum is the only population of this species known to occur as terrestrial on sandy soils. The presence of this species on rocky-outcrops interspersed with restinga is well documented in the state of Rio de Janeiro (SpeciesLink 2016). However, this species has never been reported for the herbaceous strata in restinga forests, which makes the Grumari population distinct in relation to its ecology. This species has a disjunct distribution from the coast of Santa Catarina to Rio de Janeiro states and from inland inselbergs in Espírito Santo and Bahia states (BFG 2015). All records of A. coriaceum are rupicolous populations except for Grumari. The main threat throughout the distribution of this species is habitat loss due to exploitation for ornamental rocks and civil construction (Sardou-Filho et al. 2013), which makes Grumari restinga a key area for preservation of this species due to the particular habit and to the absence of this particular threat.

Considering A. luschnathianum, the hypothetical reduction of Grumari restinga would not affect the EOO. However, the loss of natural populations in the region would probably have a negative impact on the genetic diversity of the species, since it is endemic to the state (BFG 2015) and has a very restricted distribution $\left(399 \mathrm{~km}^{2}\right)$. Also, the species is cited on the official national list of threatened plant species (Brasil 2014). The species occurs in coastal plant formations, which are constantly threatened by human activities and fire (Coelho et al. 2013). In addition, most of the herbarium records (ca. $40 \%$ ) are from the Grumari restinga, where the population is large with numerous adult individuals, which reinforces the importance of this location for conservation of A. luschnathianum.

Philodendron crassinervium is relatively common in mountains of the state of Rio de Janeiro, especially as a rupicolous plant on inselbergs or as an epiphytic and 
Table 2. Regional conservation status (Rio de Janeiro state) for Araceae species from the Grumari restinga. Values in bold represent change in the extent of occurrence (EOO) when Grumari restinga is removed. Total - EOO and area of occupancy (AOO) considering all points surveyed for Rio de Janeiro state; w/G, without Grumari (EOO and AOO excluding the occurrence in Grumari restinga); $\mathrm{n}$ /e, not evaluated. Threatened categories according to IUCN (2010): LC, least concern; NT, near threatened; VU, vulnerable; EN, endangered; CR, critically endangered; DD, data deficient. * status for the Anthurium augustinum complex (sensu Cardozo et al. 2014).

\begin{tabular}{|c|c|c|c|c|c|c|c|}
\hline Species & $\begin{array}{c}\text { EOO } \\
\text { Total (km2) }\end{array}$ & $\begin{array}{c}\text { A00 } \\
\text { Total (km2) }\end{array}$ & $\begin{array}{c}\mathrm{EOO} \mathrm{w} / \mathrm{G} \\
(\mathrm{km} 2)\end{array}$ & $\begin{array}{c}A 00 \\
W / G(k m 2)\end{array}$ & $\begin{array}{c}\text { Status RJ } \\
\text { (Coelho et al. 2014) }\end{array}$ & $\begin{array}{c}\text { Status RJ } \\
\text { (Sakuragui et al. 2011) }\end{array}$ & $\begin{array}{l}\text { National status } \\
\text { (Brasil 2014) }\end{array}$ \\
\hline $\begin{array}{l}\text { Anthurium augustinum } \\
\text { K.Koch \& Lauche }\end{array}$ & $\begin{array}{l}10544 \\
\text { VU }\end{array}$ & $\begin{array}{l}124 \\
\text { EN }\end{array}$ & $\begin{array}{c}10502 \\
\mathrm{VU}\end{array}$ & $\begin{array}{l}120 \\
\text { EN }\end{array}$ & $\mathrm{DD}^{*}$ & $\mathrm{n} / \mathrm{e}$ & $\mathrm{n} / \mathrm{e}$ \\
\hline $\begin{array}{l}\text { Anthurium coriaceum } \\
\text { (Graham) G.Don. }\end{array}$ & $\begin{array}{l}17019 \\
\text { VU }\end{array}$ & $\begin{array}{l}64 \\
\text { EN }\end{array}$ & $\begin{array}{c}16729 \\
\mathrm{VU}\end{array}$ & $\begin{array}{l}60 \\
\mathrm{EN}\end{array}$ & $\mathrm{DD}$ & $\mathrm{n} / \mathrm{e}$ & LC \\
\hline $\begin{array}{l}\text { Anthurium intermedium } \\
\text { Kunth }\end{array}$ & $\begin{array}{l}58193 \\
\text { LC }\end{array}$ & $\begin{array}{l}232 \\
\text { EN }\end{array}$ & $\begin{array}{l}58193 \\
\text { LC }\end{array}$ & $\begin{array}{l}228 \\
\mathrm{EN}\end{array}$ & $\mathrm{DD}$ & $\mathrm{n} / \mathrm{e}$ & $\mathrm{n} / \mathrm{e}$ \\
\hline $\begin{array}{l}\text { Anthurium luschnathianum } \\
\text { Kunth }\end{array}$ & $\begin{array}{l}399 \\
\text { EN }\end{array}$ & $\begin{array}{l}48 \\
\mathrm{EN}\end{array}$ & $\begin{array}{l}399 \\
\text { EN }\end{array}$ & $\begin{array}{l}44 \\
\mathrm{EN}\end{array}$ & VU & $\mathrm{n} / \mathrm{e}$ & EN \\
\hline $\begin{array}{c}\text { Anthurium maricense } \\
\text { Nadruz \& Mayo }\end{array}$ & $\begin{array}{c}17107 \\
\mathrm{VU}\end{array}$ & $\begin{array}{l}164 \\
\text { EN }\end{array}$ & $\begin{array}{c}16833 \\
\mathrm{VU}\end{array}$ & $\begin{array}{l}160 \\
\text { EN }\end{array}$ & LC & $\mathrm{n} / \mathrm{e}$ & $\mathrm{n} / \mathrm{e}$ \\
\hline $\begin{array}{l}\text { Philodendron corcovadense } \\
\text { Kunth }\end{array}$ & $\begin{array}{l}7462 \\
\mathrm{VU}\end{array}$ & $\begin{array}{l}84 \\
\text { EN }\end{array}$ & $\begin{array}{l}7462 \\
\mathrm{VU}\end{array}$ & $\begin{array}{l}80 \\
\text { EN }\end{array}$ & NT & NT & $\mathrm{n} / \mathrm{e}$ \\
\hline $\begin{array}{l}\text { Philodendron cordatum } \\
\text { Kunth ex Schott }\end{array}$ & $\begin{array}{l}23211 \\
\text { NT }\end{array}$ & $\begin{array}{l}92 \\
\text { EN }\end{array}$ & $\begin{array}{l}23211 \\
\text { NT }\end{array}$ & $\begin{array}{l}88 \\
\text { EN }\end{array}$ & LC & LC & $\mathrm{n} / \mathrm{e}$ \\
\hline $\begin{array}{c}\text { Philodendron crassinervium } \\
\text { Lindl. }\end{array}$ & $\begin{array}{c}24941 \\
\text { NT }\end{array}$ & $\begin{array}{l}96 \\
\text { EN }\end{array}$ & $\begin{array}{l}24941 \\
\text { NT }\end{array}$ & $\begin{array}{l}96 \\
\text { EN }\end{array}$ & LC & LC & $\mathrm{n} / \mathrm{e}$ \\
\hline
\end{tabular}

rupicolous plant in ombrophilous forests (Coelho et al. 2012). However, when considering the records from the state of Rio de Janeiro, those from restinga are scarce and mostly historical. The records are only from the restingas of Mauá, Copacabana, Grumari and Praia do Sul. The first two areas are associated with Guanabara Bay and the surrounding region, which nowadays is completely urbanized (Lamego 1948; Muehe \& Barros 2016). This makes the Grumari and Praia do Sul populations the only known remnants where this species occurs in this ecosystem in the state and reinforces the individual importance of each area in maintaining the species diversity, independent of the conservation status inferred.

Compared to the conservation status proposed by Coelho et al. (2014) and Sakuragui et al. (2011) for species of Araceae, which was only based on observations, the present study suggests a more critical situation in all cases. This result can be explained due to the use of the GeoCAT tool in this work, which was specifically developed to analyze distribution in relation to conservation (i.e. following IUCN criteria), unlike the previous two works that did not include calculations of any index (e.g. AOO, EOO). Moreover, Coelho et al. (2014) assessed A. angustinum as data deficient (DD), considering each species of the complex (A. maximilianii, A. laucheanum, A. lhotzkyanum and A. augustinum) as a separate entity that did not have sufficient records for a proper assessment. Based on all records, here we provide a status that is well grounded and significant. It is important to point that even for species widely distributed in the Atlantic Forest, such as P. corcovadense, $P$. cordatum and $P$. crassinervium, the regional status based on geographic distribution suggests these taxa as threatened in the state of Rio de Janeiro. Our work reinforces the need for regional lists for effective conservation practices (Gärdenfors et al. 2001).

\section{Similarity of Araceae composition in areas of restinga in the state of Rio de Janeiro}

In the areas of restinga in the state of Rio de Janeiro, 25 species and nine genera of Araceae have been recorded. The similarity analysis resulted in a dendrogram with six groups (Fig. 2): (group 1) Grumari, Maricá, Jacarepaguá and Niterói; (group 2) Jurubatiba, Massambaba and Praia Virgem; (group 3) Grussaí and Búzios; (group 4) Praia do Sul; (group 5) Marambaia; and (group 6) Copacabana and Mauá. These groups were formed with a cophenetic correlation coefficient of 0.79 , suggesting groups statistically structured in the dendrogram (Rohlf 1970; Sokal \& Rohlf 1962).

Group 1 comprises areas of restinga located in regions with significant human occupation, which has resulted in the total or partial loss of vegetation cover on the beach ridges (Lamego 1948). Jacarepaguá restinga is the only area in this group that is relatively large. It has a geomorphological genesis similar to areas of Maricá restinga in the Lake Region of the state (Muehe \& Barros 2016), but it is surrounded by coastal massifs. Group 1 is located nearby hillside forests on a crystalline basement (Pedra Branca Massif, Tijuca Massif and Tiririca Mountains). The proximity of these hills led to the occurrence of species restricted to group 1 (e.g. A. coriaceum and A. parvum N.E.Br), which are shared with the neighboring hillside forests. However, this relationship no longer occurs from the Maricá restinga northwards. An influence of hillside forests on floristic groupings in this region was also found by Moreira et al. (2014) for species of Orchidaceae in restinga areas of the state of Rio de Janeiro. Our results suggest a reduction in the influence of hillside forests in a northern direction 


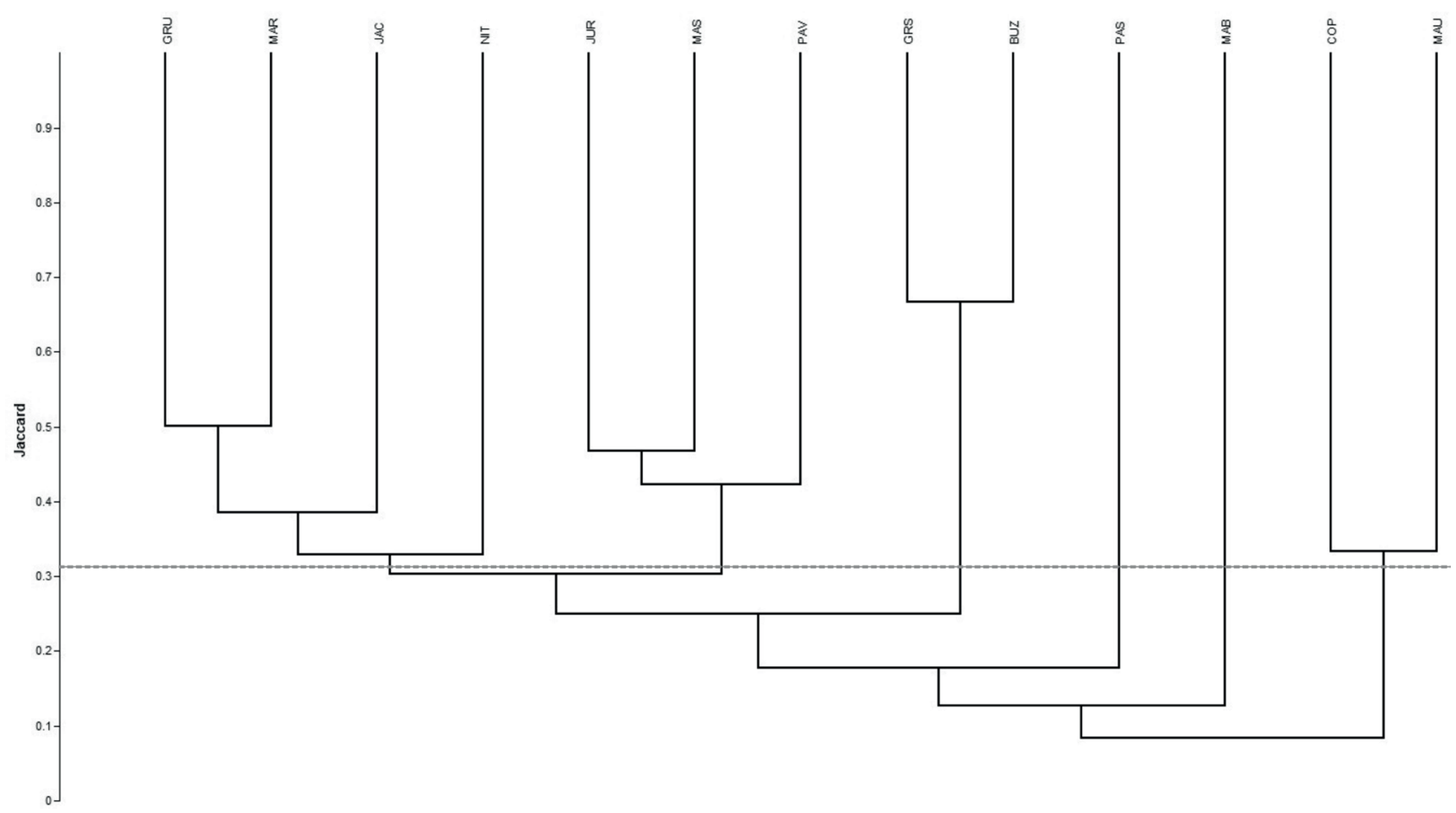

Figure 2. Jaccard similarity dendrogram for the Araceae species in areas of restinga in the state of Rio de Janeiro. Dashed line is the cutoff limit of $25 \%$ for the groups considered. BUZ, Armação de Búzios; COP, Copacabana; GRU, Grumari; GRS, Grussaí; JAC, Jacarepaguá; JUR, Jurubatiba; MAB, Marambaia; MAR, Maricá; MAS, Massambaba; MAU, Mauá; NIT, Niterói; PAS, Praia do Sul; PAV, Praia Virgem.

in the state of Rio de Janeiro, which is possibly related to the juxtaposition of the Tertiary Tableland Forest and to climatic differences along the northern coast of the state (Assumpção \& Nascimento 2000).

The influence of hillside forests was also observed in groups 4 and 5 (Praia do Sul and Marambaia, respectively), but at a lower level of similarity. However, these groups differ from group 1 by their lower species richness, which probably is the reason for their segregation.

Araceae richness in group 2 does not decrease in relation to geographic distance from the mountains. This group contains two areas of restinga located along a coastal stretch influenced by the Cabo Frio Center of Diversity (Araujo et al. 2009) and the Jurubatiba restinga, which is in the zone influenced by the Paraíba do Sul River (Muehe et al. 2006). Floristic surveys between Jurubatiba and Massambaba have already been conducted for the herbaceous strata of the open shrub community, which revealed significant similarities and higher diversity in the latter (Carvalho \& Sá 2011). In fact, Massambaba contains $60 \%$ of the Araceae richness found in the areas of restinga in the state of Rio de Janeiro, and has the most genera (7), playing an important role as phylogenetic stock in the conservation of Araceae in the state.

Group 3 comprises Grussaí and Búzios restingas and is characterized by low species richness and by sharing only two species frequent in Rio de Janeiro restingas: Anthurium harrisii and A. maricense. Based on herbarium material, although both Grussaí and Búzios have restinga formations where Araceae species are common, the loss of vegetation due to cutting, plantations and real estate speculation (Assumpção \& Nascimento 2000; Dantas et al. 2009; Rocha et al. 2007) could have influenced the low richness found. A peculiarity within this group is represented by Montrichardia linifera, which can tolerate extended droughts through its subterranean stem system (Valadares \& Sakuragui 2016).

Group 6 comprises Copacabana and Mauá restingas, which were both associated with Guanabara Bay (CPRM 2012), and no longer exist due to anthropogenic activities. The region of Guanabara Bay has suffered constant human impact and profound losses since urbanization began in Rio de Janeiro (Holzer et al. 2004; Lamego 1948). For this reason, herbarium records are not common for these areas and the few that exist are mostly over 100 years old. In the analysis, this group is formed by the presence of P. crassinervium in the two areas of restinga, but it could be considered "either" due to historical reflection or to the loss of biological diversity in these areas. The loss of restinga areas, such as Copacabana and Mauá, highlights the effect of deforestation on biological diversity. The Mauá restinga, for example, is closer to the mountain region of Rio de Janeiro (Órgãos Mountains) than to the coastal massifs previously discussed in this work. It is reasonable to think that the Araceae richness in this stretch was once much higher than it is now, due to the proximity to the mountains, which reinforces the need to preserve the lineages still present on the coastal sedimentary plain. 


\section{Concluding remarks}

In synthesis, our study revealed that APA Grumari contributes to regional conservation as a strategic geographic point for preservation of natural populations of A. augustinum, $A$. coriaceum, $A$. luschnathianum, $A$. maricense and $P$. crassinervium, because it is the last area of restinga in a preserved enclave, despite intense environmental disturbance. Besides, our similarity analysis showed heterogeneity in Araceae composition among the restingas in the state of Rio de Janeiro, where Grumari restinga belongs to the group with highest richness, and which is more influenced by the adjacent hillside forest. In addition, our study clearly shows the influence that inventories of specific areas play on the knowledge and conservation of species at a regional level. Species distributions and their conservation statuses provide important information for the ongoing "Flora of Rio de Janeiro State" project, and serve as a starting point for future national conservation plans for threatened species, such as those in this work.

As far as we know, this study is the first Araceae survey of the Grumari restinga and emphasizes aspects of conservation. Our results repeatedly indicate the importance of this small conservation unit as a key locality in the preservation of natural Araceae populations, including nationally and regionally threatened species. For this reason, it needs to be the target of campaigns that adequately inspect and effectively preserve the area. Similar studies of other plant groups, especially those that are well represented in collections, such as Myrtaceae, Orchidaceae and Rubiaceae for instance, will be fundamental in this sense, helping to construct a general panorama focused specifically on the contribution of the unit to the conservation of the regional flora.

\section{Acknowledgements}

We thank Alexandre Chagas, manager of the Grumari Environmental Protection Area, for access to the study area; the curators and staff of the herbaria visited during the study; Vera Huszar for valuable suggestions to the manuscript; the Conselho Nacional de Desenvolvimento Científico e Tecnológico, CNPq, for PhD scholarship to LSBC; and to Coordenadoria de Aperfeiçoamento de Pessoal de Ensino Superior, CAPES, for a PhD scholarship to RTV; CMS is partially supported by CNPq.

\section{References}

Araujo DSD. 2000. Análise florística e fitogeográfica das restingas do Estado do Rio de Janeiro. PhD Thesis, Universidade Federal do Rio de Janeiro, Rio de Janeiro.

Araujo DSD, Oliveira RR. 1988. Reserva Biológica Estadual da Praia do Sul (Ilha Grande, Estado do Rio de Janeiro): lista preliminar da flora. Acta Botanica Brasilica 1: 84-94.
Araujo DSD, Sá CFC, Fontella-Pereira J, et al. 2009. Área de Proteção Ambiental de Massambaba, Rio de Janeiro: caracterização fitofisionômica e florística. Rodriguésia 60: 67-96.

Assumpção J, Nascimento MT. 2000. Estrutura e composição florística de quatro formações vegetais de restinga no complexo lagunar Grussaí/ Iquipari, São João da Barra, RJ, Brasil. Acta Botanica Brasilica 14: 301-315.

Bachman S, Moat J, Hill AW, Torre J, Scott B. 2011. Supporting Red List threat assessments with GeoCAT: geospatial conservation assessment tool. ZooKeys 150: 117-126.

BFG - The Brazil Flora Group. 2015. Growing knowledge: an overview of seed plant diversity in Brazil. Rodriguésia 66: 1-29.

Brasil. 2014. Portaria $N^{\circ} 443$, de 17 de dezembro de 2014. Reconhece como espécies da flora brasileira ameaçadas de extinção aquelas constantes da "Lista Nacional Oficial de Espécies da Flora Ameaçadas de Extinção”. DOU 245: 110-221.

Cardozo AP, Temponi LG, Andrade IM, Mayo SJ, Smidt EC. 2014. A morphometric and taxonomic study of Anthurium augustinum complex (Araceae), endemic to the Brazilian Atlantic Forest. Feddes Repertorium 125: 43-58.

Carvalho DA, Sá CFC. 2011. Estrutura do estrato herbáceo de uma restinga arbustiva aberta na APA de Massambaba, Rio de Janeiro, Brasil. Rodriguésia 62: 367-378.

Coelho MAN, Gonçalves EG, Sakuragui CM, Temponi LG. 2012. Araceae. In: Wanderley MGL, Shepherd GJ, Melhem TS, Giulietti AM, Martins SE. (eds.) Flora Fanerogâmica do Estado de São Paulo Vol. 7. São Paulo, Instituto de Botânica. p. 27-71.

Coelho MAN, Maurenza D, Penedo TSA, Freitas MS. 2013. Araceae. In: Martinelli G, Moraes MA. (orgs.) Lista Vermelha da Flora do Brasil. Rio de Janeiro, Andrea Jakobsson/ Instituto de Pesquisas Jardim Botânico do Rio de Janeiro. p. 177-181.

Coelho MAN, Sakuragui CM, Calazans LSB. 2014. Araceae in Catálogo das espécies de plantas vasculares e briófitas do Estado do Rio de Janeiro. Rio de Janeiro, Instituto de Pesquisas Jardim Botânico do Rio de Janeiro. http://florariojaneiro.jbrj.gov.br. 13 Jan. 2016

Coelho MAN, Sakuragui CM, Gonçalves EG, Temponi LG, Valadares RT. 2009. Araceae. In: Stehmann JR, Forzza RC, Salino A, Sobral M, Costa DP, Kamino LY. (eds.) Plantas da Floresta Atlântica. Rio de Janeiro, Jardim Botânico do Rio de Janeiro. p. 141-145.

Cogliatti-Carvalho L, Rocha-Pessôa TC, Nunes-Freitas AF, Rocha CFD. 2008. Bromeliaceae species from coastal restinga habitats, Brazilian states of Rio de Janeiro, Espírito Santo, and Bahia. Check List 4: 234-239.

CPRM - Companhia de Pesquisa de Recursos Minerais. 2012. Geologia e recursos minerais da Folha Baía de Guanabara SF-23-Z-B-IV: Escala 1:100.000, Estado do Rio de Janeiro. Belo Horizonte, CPRM/ Universidade Estadual do Rio de Janeiro.

Dantas HGR, Lima HC, Bohrer CBA. 2009. Mapeamento da vegetação e da paisagem do município de Armação dos Búzios, Rio de Janeiro, Brasil. Rodriguésia 60: 26-38.

Gärdenfors U, Hilton-Taylor C, Mace GM, Rodriguez JP. 2001. The application of IUCN Red List criteria at regional levels. Conservation Biology 15: 1206-1212.

Giulietti AM, Rapini A, Andrade MJG, Queiroz LP, Silva JMC. 2009. Plantas raras do Brasil. Belo Horizonte, Conservação Internacional/ Universidade Estadual de Feira de Santana.

Hammer Ø, Harper DAT, Ryan PD. 2001. PAST: Paleontological statistics software package for education and data analysis. Palaeontologia Electronica 4: 9.

Holzer W, Crichyno J, Pires AC. 2004. Sustentabilidade da urbanização em áreas de restinga: uma proposta de avaliação pós-ocupação. Paisagem Ambiente: Ensaios 19: 49-66.

IUCN. 2010. Guidelines for using the IUCN Red List categories and criteria. Gland, Standards and Petitions Subcommittee Versão 8.1. http:// intranet.iucn.org/webfiles/doc/SSC/RedList/RedListGuidelines.pdf. 13 Jan. 2016.

Lamego AR. 1948. O homem e a Guanabara. Vol. 3. Rio de Janeiro, Serviço Gráfico do Instituto Brasileiro de Geografia e Estatística.

Lemos MC, Pellens R, Lemos LC. 2001. Perfil e florística de dois trechos de mata litorânea no município de Maricá - RJ. Acta Botanica Brasilica 15: 321-334. 
Loyola R, Machado N, Vila-Nova D, Martins E, Martinelli G. 2014. Áreas prioritárias para conservação e uso sustentável da flora brasileira ameaçada de extinção. Rio de Janeiro, Instituto de Pesquisas Jardim Botânico do Rio de Janeiro/ Andrea Jakobsson Estúdio.

Mayo SJ, Bogner J, Boyce PC. 1997. The Genera of Araceae. London, Royal Botanic Garden.

Moreira MM, Barberena FFVA, Lopes RC. 2014. Orchidaceae of the Grumari restinga: floristic and similarity among restingas in Rio de Janeiro state, Brazil. Acta Botanica Brasilica 28: 321-326.

Muehe D, Lima CF, Barros FML. 2006. Rio de Janeiro. In: Mueher D. (org.) Erosão e progradação do litoral brasileiro. Brasília, Ministério do Meio Ambiente. p. 265-296.

Muehe D, Barros FML. 2016. The beaches of Rio de Janeiro. In: Short AD, Klein AHF. (eds.) Brazilian beach systems, coastal research. Dordrecht, Springer International Publishing. p. 363-396.

Paz J, Bove CP. 2007. Hidrófitas vasculares da Lagoa de Carapebus, Parque Nacional da Restinga de Jurubatiba, Rio de Janeiro, Brasil. Revista Brasileira de Biociências 5: 495-497.

Pederneiras LC, Costa AF, Araujo DSD. 2014. Padrões de distribuição geográfica das restingas do Rio de Janeiro: Cannabaceae, Moraceae, Ulmaceae e Urticaceae. Saarbrücken, Novas Edições Acadêmicas.

Pereira MCA, Cordeiro SZ, Araujo DSD. 2004. Estrutura do estrato herbáceo na formação aberta de Clusia do Parque Nacional da Restinga de Jurubatiba, RJ, Brasil. Acta Botanica Brasilica 18: 677-687.

Pereira OJ. 2003. Restinga: origem, estrutura e diversidade. In: Jardim MAG, Bastos MNC, Santos JUM. (orgs.) Desafios da botânica brasileira no novo milênio: inventário, sistematização e conservação da biodiversidade vegetal. Vol. 1. Belém, Sociedade Botânica do Brasil/ Universidade Federal Rural da Amazônia/ Museu Paraense Emílio Goeldi. p. 177-179.

Pereira OJ, Araujo DSD. 2000. Análise florística das restingas dos estados do
Espírito Santo e Rio de Janeiro. In: Esteves FA, Lacerda LD. (orgs.) Ecologia de restingas e lagoas costeiras. Rio de Janeiro, NUPEM/UFRJ. p. 25-63.

Rocha CFD, Bergallo HG, Sluys M, Alves MAS, Jamel CE. 2007. The remnants of restinga habitats in the Brazilian Atlantic Forest of Rio de Janeiro state, Brazil: Habitat loss and risk of disappearance. Brazilian Journal of Biology 67: 263-273.

Rohlf FJ. 1970. Adaptive hierarchical clustering schemes. Systematic Biology 19: 58-82.

Sakuragui CM, Calazans LSB, Morais EB, Coelho MAN, Pellegrini MOO. 2011. Diversity and conservation of Philodendron Schott (Araceae) in Atlantic Forest of Rio de Janeiro State, Brazil. Feddes Repertorium 122: 472-496.

Sardou-Filho R, Matos GMM, Mendes VA, Iza ERHF. 2013. Atlas de rochas ornamentais do estado do Espírito Santo. Brasília, CPRM.

Sokal RR, Rohlf FJ. 1962. The comparison of dendrograms by objective methods. Taxon 11: 33-40.

SpeciesLink. 2016 Sistema de informação distribuído para coleções biológicas. Campinas, Centro de Referência em Informação Ambiental. www.splink.org.br. 13 Jan. 2016.

Thiers B. 2016 - continuously updated. Index Herbariorum: A global directory of public herbaria and associated staff. New York, New York Botanical Gardens' Virtual Herbarium. http://sweetgun.nybg. org/ih/. 13 Jan. 2016.

Valadares RT, Martins MLL, Coelho MAN. 2010. O gênero Anthurium Schott (Araceae) no Parque Estadual Paulo César Vinha, Guarapari, Espírito Santo. Natureza Online 8: 107-113.

Valadares RT, Sakuragui CM. 2016. A família Araceae Juss. nas restingas do Estado do Espírito Santo. Boletim do Museu de Biologia Mello Leitão (N. Ser) 38: 187-255.

Vidal MRR, Vidal WN. 1977/1978. A vegetação da praia de Grumari. Oréades 10/11: 6-21. 